\title{
Asma Anaçlarının in Vitro'da Büyüme Performansları ile Besin Elementi Alım Düzeylerinin Belirlenmesi
}

\author{
Serpil TANGOLAR ${ }^{1 *}$, Kaan Fethi KAYA ${ }^{1}$, Nuray MEŞE ${ }^{1}$, \\ Melike $\mathrm{ADA}^{1}$, Ayfer ALKAN TORUN ${ }^{2}$
}

\section{ÖZ}

Çalışmada, 5BB, 41B, 140Ru, SO4, 110R, 1103P, Salt Creek ve Harmony anaçlarının in vitro koşullarda bitki büyüme performansları ile besin elementi alım düzeylerinin belirlenmesi amaçlanmıştır. Anaçların bir gözlü yeşil mikro çeliklerinden, in vitro'da $1 \mathrm{mg} \mathrm{L}^{-1} \mathrm{BAP}$ içeren MS ortamında elde edilen sürgünler, $1 \mathrm{mg} \mathrm{L}^{-1}$ IBA içeren ortamda 45 gün süreyle kültüre alınarak bunlarda kök oluşumu ve sürgün büyümesi sağlanmıştır. Sonuçta, en yüksek sürgün ve kök gelișim performansını sırasıyla 110R ve Harmony anaçlarının gösterdiği belirlenmiştir. Azot bakımından 5BB, 1103P ve 110R; P ve K için SO4; Ca için Salt Creek; Mg için 140Ru; Cu için Salt Creek; Mn için 110R; Fe için 140Ru ve Zn için 5BB'nin en yüksek değer veren anaçlar olduğu saptanmıştır.

Anahtar kelimeler: Asma anacı, doku kültürü, makroelement, mikroelement, SPAD değeri

\section{Determination of In Vitro Growth Performances and Nutrient Uptake Levels of Vine Rootstocks}

\begin{abstract}
This study aimed to determine the plant growth performances and nutrient intake levels of 5BB, 41B, 140Ru, SO4, 110R, 1103P, Salt Creek, and Harmony rootstocks under in vitro conditions. The shoots obtained from one-bud green micro cuttings of rootstocks in MS medium containing 1 $\mathrm{mg} \mathrm{L}^{-1} \mathrm{BAP}$ in vitro were cultured in a medium containing $1 \mathrm{mg} \mathrm{L}^{-1}$ IBA for 45 days, and root formation and shoot growth was achieved in them. As a result of the research, it was determined that the highest shoot and root development performance among rootstocks were in $110 \mathrm{R}$ and Harmony rootstocks, respectively. It was determined that 5BB, $1103 \mathrm{P}$ and $110 \mathrm{R}$ in terms of nitrogen, SO4 for P and K; Salt Creek for Ca; $140 \mathrm{Ru}$ for $\mathrm{Mg}$; Salt Creek for $\mathrm{Cu}$; 110R for Mn; $140 \mathrm{Ru}$ for $\mathrm{Fe}$ and $5 \mathrm{BB}$ for $\mathrm{Zn}$ were the rootstocks with the highest values.
\end{abstract}

Keywords: Grape rootstock, tissue culture, macroelement, microelement, SPAD value

ORCID ID (Yazar sirasına göre)

0000-0002-5563-1972， 0000-0002-8303-6628， 0000-0002-2268-3960， 0000-0001-5182-0787, 0000-0002-8493-5828

\footnotetext{
Yayın Kuruluna Geliş Tarihi: 19.11.2021

Kabul Tarihi: 24.12.2021

${ }^{1}$ Çukurova Üniversitesi Ziraat Fakültesi Bahçe Bitkileri Bölümü, Adana

${ }^{2}$ Çukurova Üniversitesi Ziraat Fakültesi Toprak Bilimi ve Bitki Besleme Bölümü, Adana

*E-posta: stangolar@cu.edu.tr
} 


\section{Asma Anaçlarının in Vitro'da Büyüme Performansları ile Besin Elementi Alım Düzeylerinin Belirlenmesi}

\section{Giriş}

Ilıman iklim bitki türü olarak kabul edilen asma, sıcak yazlar ile 1lıman kıșlara yüksek oranda adapte olmuştur ve genel olarak y1ll1k $10-20{ }^{\circ} \mathrm{C}$ izoterme sahip alanlarda yetiştiriciliği yapılabilmektedir (Ağaoğlu, 2002). Sofralık, kurutmalık, şaraplık-şıralık gibi değişik tüketim ve değerlendirme alanlarına sahip olan üzüm, dünyada geçmişten günümüze ekonomik yapıya önemli etkileri olan meyvelerden birisi olmuştur (Çelik, 2011). Ancak 19. yüzyılın ikinci yarısından itibaren filoksera ve nematod zararlıları ile toprak kaynaklı stres faktörleri üzüm yetiştiriciliğinin sürdürülebilirliğini tehdit etmeye başlamıştır (Mahajan ve Tuteja, 2005). $\mathrm{Bu}$ y1llardan itibaren bașta filoksera zararlısı nedeniyle dünyada olduğu gibi ülkemizde de bağcılık için anaç kullanma zorunluluğu doğmuştur. Vitis vinifera L. çeşitleri filoksera ve nematod zararlıları dışında kalan toprak ve iklim koşullarına çok iyi adapte olmalarına rağmen, Amerikan asma anaçlarının toprak nemi, kuraklık, tuzluluk, aktif kireç gibi faktörlere dayanımlanı birbirinden farklıdır (Ağaoğlu, 2002; Dardeniz ve ark., 2006; Satisha ve ark., 2006; Çelik, 2011; Babalık, 2012; Suarez ve ark., 2019; Prinsi ve ark., 2021). Bu nedenle bağcılıkta olumsuz çevresel faktörlerin niteliğine göre farklı anaçların kullanılması gerekmiştir. Bunların dışında üzümlerin olgunlaşma zaman1, büyümesi, verimi, kalitesi ve beslenmesinde de anaçların önemli etkisi bulunmaktadır (Hale ve Brien, 1978; Tangolar ve Ergenoğlu, 1989; Fisarakis ve ark., 2001; Çelik ve Kısmalı, 2004; Ibacache ve Sierra, 2009; Keller ve ark., 2012; Wang ve ark., 2019). Arazi koşullarında yetiştiricilikte (in situ), besin elementlerinin çok farklı seviyelerde bulunarak antagonizm etkisi oluşturması gibi bazı özellikleri de anaçların beslenmesini sonuç olarak üzüm verim ve kalitesini etkileyebilmektedir (Troncoso ve ark., 1999; Çelik, 2011; Fozouni ve ark., 2012). Ağaoğlu (2002) asma yetiştiriciliğinde 4 makro $(\mathrm{N}, \mathrm{P}, \mathrm{K}, \mathrm{Mg}$ ) ve 3 mikro (B, $\mathrm{Zn}, \mathrm{Fe}$ ) elementin önemli olduğunu, asmaların beslenme, sulama gibi kültürel işlemlerle verim, kalite, aroma, renk maddesi gibi özelliklerinin değiştirilebileceğini belirtmiştir. Yapılan çalışmalar 1şı̆̆ında anaçların beslenme üzerinde önemli etkilerinin olduğu belirlenmiştir. Ancak bu çalıșmaların çoğu dıș koșullarda biyotik ve abiyotik etkilerin varlığında gerçekleştirildiğinden anaçların besin elementi tercihleri konusu tam olarak aydınlatılamamıştır.

In situ'da gerçekleştirilen çalışmalar yanında in vitro koşullarda da anaçların stres koşullarında verdiği tepkiler araştırılmıştır (Bavaresco ve ark., 1993; Hamrouni ve ark., 2008; Y1lmaz ve ark., 2008; Alizadeh ve ark., 2010; Barakat ve ark., 2019; Meșe ve Tangolar, 2019; Mohsen ve ark., 2020). Ancak anaçların in vitro beslenmesi ile ilgili çalışmalar sınırlı sayıdadır (Troncoso ve ark., 1999; Popescu ve ark., 2015; Edriss ve ark., 2016). Troncoso ve ark. (1999) çalışmalarında on anacın (41B, R. Lot, 110R, 140Ru, 161-49 C, 13.5 Evex, Ramsey, 196-17 Castel, $\mathrm{CH}-1$ ve $\mathrm{CH}-2$ ) in vitro' da yetişen bitkilerinde makro element düzeylerini belirlemiş, Edriss ve ark. (2016) ise çalışmalarını dört anaç (Salt Creek, Freedom, Dogridge ve Richter) ile gerçekleştirmişlerdir.

Tüm bu bilgilerin varlığında ülkemizde önemli olan anaçların hangi besin elementine hangi miktarda ihtiyaç duyduğu sorusu günümüze kadar cevapsız kalmıştır. İşte bu çalışma in vitro'da anaçların ihtiyaç duyduğu besin elementlerinin konsantrasyonlarının belirlenmesi ve beslenme programlarının oluşturulabilmesi amaciyla gerçekleştirilmiştir.

\section{Materyal ve Yöntem Materyal}

Çalışmada bitki materyali olarak Ç.Ü. Ziraat Fakültesi Bahçe Bitkileri Bölümü Araştırma ve Uygulama Bağı'nda yetiştirilen ve bağcılıkta kullanımı yaygın olan 41B, 5BB, SO4, 110R, 1103P, 140Ru, Salt Creek ve Harmony anaçlarının tek gözlü yeşil mikro çelikleri kullanılmıștır (Cizelge 1). Calıșmanın doku kültürü uygulamaları aynı bölümde yer alan Prof. Dr. Saadet Büyükalaca Doku Kültürü Laboratuvarı'nda, bitki besin elementi analizleri ise Toprak Bilimi ve Bitki Besleme Bölümü Fizyoloji Laboratuvar'inda gerçekleştirilmiştir. 


\section{Asma Anaçlarının in Vitro'da Büyüme Performansları ile Besin Elementi Alım Düzeylerinin Belirlenmesi}

Çizelge 1. Anaçların Bazı Özellikleri (Ağaoğlu, 1999; Çelik, 2011)

\begin{tabular}{lcccc} 
Anaçlar & $\begin{array}{c}\text { Gelişme } \\
\text { Kuvveti (a) }\end{array}$ & $\begin{array}{c}\text { Filokseraya } \\
\text { Dayanım (b) }\end{array}$ & $\begin{array}{c}\text { Nematoda } \\
\text { Dayanım (b) }\end{array}$ & $\begin{array}{c}\text { Aktif Kirece } \\
\text { Dayanım (\%) }\end{array}$ \\
\hline 5BB & 2 & 4 & 3 & 20 \\
41B & 2 & 4 & 1 & 40 \\
$140 \mathrm{Ru}$ & 4 & 4 & 3 & 20 \\
SO4 & 2 & 4 & 4 & 17 \\
$110 \mathrm{R}$ & 3 & 4 & 2 & 17 \\
$1103 \mathrm{P}$ & 3 & 4 & 2 & 17 \\
Salt Creek & 4 & 2 & 4 & - \\
Harmony & 3 & 2 & 4 & - \\
\hline
\end{tabular}
(a) 4: Yüksek; 1: Düşük
(b) 5: Çok Dayanıklı; 1: Çok Duyarlı

\section{Yöntem}

\section{Besi Ortamının Bileşimi ve Hazırlığı}

Çalışmanın bütün aşamalarında temel besi ortamı olarak MS (Murashige and Skoog, 1962) (Çizelge 2) kullanılmıştır. MS besi ortamına yeşil mikro çeliklerden sürgün elde edilmesi aşamasında $\quad 1 \quad \mathrm{mg} \quad \mathrm{L}^{-1}$ BAP (6Benzylaminopurine); elde edilen sürgünlerin köklendirilmesi ve büyütülmesi aşamasında ise $1 \mathrm{mg} \mathrm{L}^{-1}$ IBA (Indole -3-butyric acid) ilave edilmiştir. Bütün kültür aşamalarında besi ortamına $30 \mathrm{~g} \mathrm{~L}^{-1}$ sakkaroz ilave edilmiş, $\mathrm{pH}$ 5.8'e ayarlanmış ve $8 \mathrm{~g} \mathrm{~L}^{-1}$ agar eklenmiştir. Hazırlanan besi ortam $1 \quad 15 \times 2.5 \mathrm{~cm}$ boyutlarındaki deney tüplerine 10 'ar $\mathrm{mL}$ olacak şekilde dağıtılmış ve $121{ }^{\circ} \mathrm{C}$ ' de $1.2 \mathrm{~atm}$ basınç altında otoklavlanmıştır.

\section{Eksplant Hazırlığı ve Bitki Elde Edilmesi}

Çalışmada eksplant olarak kullanılan mikro çelikler, mayıs-haziran aylarında yaz sürgünlerinin $10 \mathrm{~cm}$ 'lik uç kısımlarının bir göz içeren parçaları olarak hazırlanmıştır. Hazırlanan çelikler steril kabin içerisinde $\% 20$ 'lik ticari sodyum hipoklorit ve 1-2 damla Tween 20 eklenen çözeltide 15 dakika bekletmenin ardından $3 \mathrm{kez}$ steril saf su ile durulanmış ve $1 \mathrm{mg} \mathrm{L}^{-1} \mathrm{BAP}$ eklenmiş MS besi ortamına dikilmiştir. Burada 4 hafta süreyle kültüre alınan çeliklerde sürgün oluşumu sağlanmıştır. $\mathrm{Bu}$ sürgünlerden $2 \mathrm{~cm}$ uzunluğunda 2-3 yaprak oluşturanlar seçilerek 1 $\mathrm{mg} \mathrm{L}^{-1}$ IBA ilave edilmiş MS ortamında 45 gün süreyle kültüre alınmıştır. Kültür sonunda elde edilen bitkiciklerde çalışmada öngörülen incelemeler yapılmıştır.
Çizelge 2. MS besi ortamının kimyasal içeriği (Babaoğlu ve ark., 2001)

\begin{tabular}{|c|c|}
\hline Bileşenler & $\begin{array}{c}\text { Kültür ortamındaki } \\
\text { konsantrasyon }\left(\mathrm{mg} \mathrm{L}^{-1}\right)\end{array}$ \\
\hline $\mathrm{KNO}_{3}$ & 1900 \\
\hline $\mathrm{NH}_{4} \mathrm{NO}_{3}$ & 1650 \\
\hline $\mathrm{MgSO}_{4} 7 \mathrm{H}_{2} \mathrm{O}$ & 370 \\
\hline $\mathrm{CaCl}_{2} \cdot 2 \mathrm{H}_{2} \mathrm{O}$ & 440 \\
\hline $\mathrm{KH}_{2} \mathrm{PO}_{4}$ & 170 \\
\hline $\mathrm{MnSO}_{4} 4 \mathrm{H}_{2} \mathrm{O}$ & 22.3 \\
\hline KI & 0.83 \\
\hline $\mathrm{H}_{3} \mathrm{BO}_{3}$ & 6.2 \\
\hline $\mathrm{ZnSO}_{4} .7 \mathrm{H}_{2} \mathrm{O}$ & 8.6 \\
\hline $\mathrm{CuSO}_{4} .5 \mathrm{H}_{2} \mathrm{O}$ & 0.025 \\
\hline $\mathrm{Na}_{2} \mathrm{MoO}_{4} \cdot 2 \mathrm{H}_{2} \mathrm{O}$ & 0.25 \\
\hline $\mathrm{CoCl}_{2} \cdot 6 \mathrm{H}_{2} \mathrm{O}$ & 0.025 \\
\hline $\mathrm{FeSO}_{4 .} 7 \mathrm{H}_{2} \mathrm{O}$ & 27.8 \\
\hline $\mathrm{Na}_{2}$ EDTA & 37.3 \\
\hline Nikotinik asit & 0.5 \\
\hline Pridoksin- $\mathrm{HCl}$ & 0.5 \\
\hline Thiamin- $\mathrm{HCl}$ & 0.1 \\
\hline myo-inositol & 100 \\
\hline Glisin & 2 \\
\hline Sakkaroz & 30000 \\
\hline
\end{tabular}

\section{Kültür Koşulları}

Çalışma süresince kültür odasının sıcaklığı $25 \pm 1{ }^{\circ} \mathrm{C}$, fotoperiyodu 16 saat ve 1şılklanmas1 3000-4000 lüks (11000-15000 watt $\left.\mathrm{m}^{-2}\right)$ şiddetinde olacak şekilde ayarlanmıştır. Işıklanma için Cool daylight tipi TLD 36 w/54 floresan lambalar kullanılmıştır (Tangolar ve ark., 2008; Meşe ve Tangolar, 2019). 


\section{Asma Anaçlarının in Vitro'da Büyüme Performansları ile Besin Elementi Alım Düzeylerinin Belirlenmesi}

\section{İncelenen Özellikler Sürgün ve Kök Özellikleri}

Kültür sonunda elde edilen bitkiciklerde; sürgün uzunluğu $(\mathrm{cm})$ ve ortalama kök uzunluğu $(\mathrm{cm})$ cetvel yardımıyla, boğum sayısı (n) ve kök sayısı (n) sayılarak belirlenmiştir. Sürgün ve kök yaş ağırlığ hassasiyette terazi ile, sürgün ve kök kuru ağırlıkları (g) ise $65^{\circ} \mathrm{C}^{\prime}$ de 24 saat süre ile etüvde bekletildikten sonra $0.001 \mathrm{~g}$ hassasiyette terazi ile tartılarak (Meşe ve Tangolar, 2019) belirlenmiştir. Yaprak klorofil içeriği SPAD metre ile (SPAD-502, Konica Minolta Sensing, Inc., Tokyo, Japan) her bitkide ikişer yaprakta ölçülmüştür.

\section{Bitki Besin Elementi Analizleri}

Bitki besin elementi analizlerinde bitkiciklerin sürgün kısımları kullanılmıştır. Sürgünler, $65^{\circ} \mathrm{C}$ etüvde 24 saat kurutulduktan sonra porselen havanda öğütülerek besin elementi analizlerine hazır hale getirilmiştir. Azot (N) konsantrasyonu Kjeldahl yöntemine (Bremner, 1965) göre belirlenmiştir. Fosfor (P), Potasyum $(\mathrm{K})$, Magnezyum (Mg), Kalsiyum (Ca), Demir $(\mathrm{Fe})$, Bakır $(\mathrm{Cu})$, Çinko $(\mathrm{Zn})$ ve Mangan $(\mathrm{Mn})$ konsantrasyonlarını belirlemek için ögütülmüş örneklerden $0.2 \mathrm{~g}$ tartılarak $550^{\circ} \mathrm{C}$ 'de kül fırınında 5.5 saat yakılmıştır. Yakma işleminden sonra oluşan küle $2 \mathrm{~mL} \mathrm{1/3'lük}$ HCL çözeltisi ile $18 \mathrm{~mL}$ saf su eklenerek mavi bant filtre kâğıdından süzülmüş ve vial içerisine alınmıştır. Fosfor tayini vanadomolibdofosforik asit sarı renk yöntemine göre Shimadzu model UV 1201 spektrofotometresi kullanılarak saptanmıştır (Kacar, 1972). Potasyum Eppendorf Elex $6361 \quad$ Fleymfotometresi kullanılarak belirlenmiștir. Bitki örneklerinde kalsiyum, magnezyum, demir, çinko, mangan ve bakır konsantrasyonları, Atomik Absorpsiyon spektrofotometre cihazı (Analytik jena contrAA 700) ile yapilan okumalarla gerçekleştirilmiştir.

\section{Deneme Deseni ve İstatistiki Analiz}

$\mathrm{Bu}$ çalışma tesadüf parselleri deneme desenine göre 3 tekerrürlü ve her tekerrürde 10 bitki olacak şekilde yürütülmüştür. Deneme sonucunda elde edilen verilere JMP istatistik paket programindan (v8.00, SAS Institute Inc., USA) yararlanilarak varyans analizi uygulanmış, farklı grupların belirlenmesinde $\% 5$ önem seviyesinde LSD testinden yararlanılmıştır.

\section{Bulgular ve Tartışma \\ Bulgular}

Çalışmada kullanılan sekiz anaç arasında boğum sayıları bakımından önemli bir farklılık tespit edilememiștir. Sürgün uzunlukları bakımından en güçlü büyüyen çeşit 110R (6.75 $\mathrm{cm}$ ), en zayıf büyüyen çeşit ise Harmony (4.53 $\mathrm{cm})$ olmuştur. Diğer çeşitler istatiksel olarak ara grupta yer almıştır. Sürgün yaş ve kuru ağırlıkları incelendiğinde Salt Creek (sırasıyla, 0.446 ve $0.065 \mathrm{~g}$ ), Harmony (sirasiyla, 0.352 ve $0.062 \mathrm{~g}$ ) ve SO4 (sirasiyla, 0.330 ve $0.055 \mathrm{~g}$ ) anaçları en fazla kuru madde biriktiren genotipler olurken, 5BB (sirasiyla, 0.254 ve $0.032 \mathrm{~g}$ ) en düşük değer alınan anaç olarak gözlemlenmiştir. SPAD değerlerinin 30.5 (41B ve SO4) ile 27.5 (1103P) arasında değiştiği belirlenmiștir (Çizelge 3).

5BB çeşidinin en uzun $(7.76 \mathrm{~cm})$ ve en az sayıda kök (2.90 adet) oluşturduğu gözlemlenmiştir. 5BB anacının en uzun köklere sahip olmasının yanı sıra kök yaş ve kuru ağırlı̆̆ 1 bakımından da zayıf kaldığı tespit edilmiştir. Ortalama kök uzunluğu $5.35 \mathrm{~cm}$ olan 41B anacının, 5BB' ye göre $\% 30$ daha kısa kök oluşturduğu belirlenmiş ve bu özellik açısından diğer anaçlara göre en kısa kök elde edilen anaç olarak saptanmıştır. Salt Creek, Harmony, $140 \mathrm{Ru}, \mathrm{SO} 4,110 \mathrm{R}$ ve $1103 \mathrm{P}$ anaçları ortalama kök uzunluğu bakımından aynı ara grupta yer alarak ara değerler vermiş ve SO4 dişındaki bu çeşitlerde en yüksek kök sayısı elde edilmiştir. Kök yaş ve kuru ağırlığına göre anaçlar arasında önemli farklılık saptanmış ve büyükten küçüğe doğru sıralama; Harmony, Salt Creek, $1103 \mathrm{P}, 110 \mathrm{R}, 140 \mathrm{Ru}, \mathrm{SO} 4,41 \mathrm{~B}$ ve 5BB şeklinde olmuştur (Çizelge 4). 


\section{Asma Anaçlarının in Vitro'da Büyüme Performansları ile Besin Elementi Alım Düzeylerinin Belirlenmesi}

Çizelge 3. Farklı asma anaçlarının in vitro' da sürgün gelişme özellikleri ve SPAD değerleri

\begin{tabular}{|c|c|c|c|c|c|}
\hline Anaçlar & $\begin{array}{c}\text { Sürgün } \\
\text { uzunluğu } \\
\left(\mathrm{cm} \mathrm{bitki}^{-1}\right)\end{array}$ & $\begin{array}{c}\text { Boğum } \\
\text { say1sı } \\
(\mathrm{n} \text { bitki-1) } \\
\end{array}$ & $\begin{array}{c}\text { Sürgün yaş } \\
\text { ağırlığ } 1 \\
\left(\mathrm{~g} \text { bitki }{ }^{-1}\right) \\
\end{array}$ & $\begin{array}{l}\text { Sürgün kuru } \\
\text { ağırlığ1 } \\
\left(\mathrm{g} \mathrm{bitki}{ }^{-1}\right)\end{array}$ & $\begin{array}{c}\text { SPAD } \\
\text { okumaları }\end{array}$ \\
\hline $5 \mathrm{BB}$ & $5.55 \mathbf{a b}^{\mathrm{x}}$ & 8.4 & $0.254 \mathrm{e}$ & $0.032 \mathrm{e}$ & 29.5 abc \\
\hline $41 B$ & $6.03 \mathbf{a b}$ & 8.3 & 0.307 bcd & 0.049 cd & $30.5 \mathbf{a}$ \\
\hline 140Ru & $5.85 \mathbf{a b}$ & 9.0 & 0.293 cde & 0.052 bcd & $30.1 \mathbf{a b}$ \\
\hline $\mathrm{SO} 4$ & $5.84 \mathbf{a b}$ & 8.8 & $0.330 \mathbf{b c}$ & 0.055 abc & $30.5 \mathbf{a}$ \\
\hline $110 \mathrm{R}$ & $6.75 \mathbf{a}$ & 8.9 & 0.260 de & $0.045 \mathrm{~cd}$ & $27.8 \mathbf{d}$ \\
\hline $1103 P$ & $5.15 \mathbf{a b}$ & 8.5 & $0.268 \mathrm{de}$ & 0.044 de & $27.5 \mathrm{~d}$ \\
\hline Salt Creek & $6.07 \mathbf{a b}$ & 8.4 & $0.446 \mathbf{a}$ & $0.065 \mathbf{a}$ & 28.4 bcd \\
\hline Harmony & $4.53 \mathbf{b}$ & 9.2 & $0.352 \mathbf{b}$ & $0.062 \mathbf{a b}$ & 28.2 cd \\
\hline LSD \%5 & 1.82 & Ö.D. & 0.048 & 0.011 & 1.77 \\
\hline$p$ & 0.3162 & 0.8812 & 0.0002 & 0.0030 & 0.0165 \\
\hline
\end{tabular}

${ }^{x}$ Aynı sütunda farklı harflerle gösterilen ortalamalar arasında istatistiki düzeyde önemli farklılık bulunmaktadır ( $p \leq 0.05)$. Ö.D.: Önemli Değil.

Çizelge 4. Farklı asma anaçlarının in vitro' da kök özellikleri

\begin{tabular}{|c|c|c|c|c|}
\hline Anaçlar & $\begin{array}{c}\text { Ortalama } \\
\text { kök uzunluğu } \\
\left(\mathrm{cm} \mathrm{bitki-1)}^{-1}\right)\end{array}$ & $\begin{array}{c}\text { Kök } \\
\text { say1s1 } \\
\left(\text { n bitki }^{-1}\right)\end{array}$ & $\begin{array}{l}\text { Kök yaş } \\
\text { ağırlığ1 } \\
\left(\mathrm{g} \mathrm{bitki}^{-1}\right)\end{array}$ & $\begin{array}{l}\text { Kök kuru } \\
\text { ağırlığg } \\
\left(\mathrm{g} \mathrm{bitki}^{-1}\right)\end{array}$ \\
\hline $5 \mathrm{BB}$ & $7.76 \mathbf{a}^{\mathbf{x}}$ & $2.90 \mathrm{~b}$ & $0.112 \mathrm{~d}$ & $0.012 \mathrm{c}$ \\
\hline $41 \mathrm{~B}$ & $5.35 \mathbf{b}$ & $4.33 \mathbf{a b}$ & 0.167 cd & $0.020 \mathbf{b c}$ \\
\hline $140 \mathrm{Ru}$ & $7.21 \mathbf{a b}$ & $4.78 \mathbf{a}$ & 0.300 bcd & $0.030 \mathbf{b c}$ \\
\hline $\mathrm{SO} 4$ & $6.53 \mathbf{a b}$ & $4.63 \mathbf{a b}$ & $0.205 \mathrm{~cd}$ & 0.024 bc \\
\hline $110 \mathrm{R}$ & $6.55 \mathbf{a b}$ & $5.15 \mathrm{a}$ & 0.344 bc & $0.033 \mathbf{b}$ \\
\hline $1103 \mathrm{P}$ & $7.20 \mathbf{a b}$ & $4.80 \mathbf{a}$ & $0.360 \mathbf{b c}$ & $0.037 \mathbf{b}$ \\
\hline Salt Creek & $6.82 \mathbf{a b}$ & $4.94 \mathbf{a}$ & $0.416 \mathbf{b}$ & $0.034 \mathbf{b}$ \\
\hline Harmony & $6.30 \mathbf{a b}$ & $4.83 \mathbf{a}$ & $0.643 \mathbf{a}$ & $0.060 \mathbf{a}$ \\
\hline LSD $\% 5$ & 2.35 & 1.81 & 0.208 & 0.019 \\
\hline$p$ & 0.4838 & 0.2566 & 0.0071 & 0.0119 \\
\hline
\end{tabular}

${ }^{\mathrm{x}}$ Aynı sütunda farklı harflerle gösterilen ortalamalar arasında istatistiki düzeyde önemli farklılık bulunmaktadır $(p \leq 0.05)$. Ö.D.: Önemli Değil.

Çizelge 5'e bakıldığında genotiplerin besi ortamindan azot elementini \%3.50-4.50 aralığında alabildikleri saptanmış ve asma anaçları içerisinde azotu en iyi alabilen çeşitlerin 5BB, 1103P ve 110R oldukları belirlenmiştir. $\mathrm{Bu}$ anaçları sırasıyla $\mathrm{SO} 4$, Harmony, Salt Creek, 140Ru ve 41B izlemiştir. Besi ortamındaki $\mathrm{P}$ ve $\mathrm{K}$ element alımı için SO4, Ca element alımı için Salt Creek ve $\mathrm{Mg}$ element alımı için 140Ru ön plana çıkan genotipler olmuştur. Makro elementlerden P, K, $\mathrm{Ca}$ ve $\mathrm{Mg}$ elementlerini en az alabilen anaçların ise $110 \mathrm{R}$ ve $1103 \mathrm{P}$ oldukları tespit edilmiştir. 110R, 1103P, Harmony asma anaçları bünyelerine $\% 2$ konsantrasyonu altında potasyum alımı gerçekleştirirken diğer genotiplerin potasyum alımları \%2'nin üzerinde olmuştur. Fosfor konsantrasyonları bakımından 5BB, 41B, Salt Creek, Harmony ve $140 \mathrm{Ru}$; Ca bakımından 5BB, 41B, SO4, Harmony, 140Ru; $\mathrm{Mg}$ bakımından 5BB, 41B, Salt Creek, Harmony, SO4 anaçları birbirine yakın değerler almışlardır. Bitkide analizlenen $\mathrm{Cu}$ element konsantrasyonu için Salt Creek, Mn için 110R, Fe için 140Ru ve $\mathrm{Zn}$ konsantrasyonu için 5BB' nin en yüksek değer veren anaçlar olduğu saptanmıştır. Bakır elementini bünyesine en az alabilen anacın 1103P olduğu, diğer anaçların ise 2.5-3.5 ppm aralığında $\mathrm{Cu}$ alabildikleri belirlenmiştir. Mangan miktarı bakımından 110R çeşidini (401.8 ppm) sirasıyla 140Ru (346.8 ppm), 1103P (320.1 ppm), SO4 (308.1 


\section{Asma Anaçlarının in Vitro'da Büyüme Performansları ile Besin Elementi Alım Düzeylerinin Belirlenmesi}

ppm), 41B (253.0 ppm), Harmony (240.5 ppm), Salt Creek (239.3 ppm) ve en düşük değer ile 5BB (226.0 ppm) takip etmiştir. En düşük $\mathrm{Fe}$ elementi alımı 41B (169.3 ppm), Harmony (167.1 ppm) ve Salt Creek (156.7 ppm) anaçlarında belirlenmiştir. Diğer genotiplerin $\mathrm{Fe}$ değerleri ise 200-300 ppm arasında değişmiştir. En düşük $\mathrm{Zn}$ değeri $41 \mathrm{~B}$ ve $110 \mathrm{R}$ $(57.1 \mathrm{ppm})$ anaçlarında tespit edilmiştir. Tablodan, anaçların en düşük-en yüksek mikro element konsantrasyonları arasında yaklaşık \%50'lik bir fark oluştuğu anlaşılmaktadır (Çizelge 6).

Çizelge 5. Farklı asma anaçlarının in vitro'da makro besin element konsantrasyonları (\%)

\begin{tabular}{lccccc}
\hline Anaçlar & $\mathrm{N}$ & $\mathrm{P}$ & $\mathrm{K}$ & $\mathrm{Ca}$ & $\mathrm{Mg}$ \\
\hline $5 \mathrm{BB}$ & $4.26 \mathbf{a}^{\mathrm{x}}$ & $0.37 \mathbf{b}$ & $2.48 \mathbf{b}$ & $0.61 \mathbf{b}$ & $0.33 \mathbf{c}$ \\
$41 \mathrm{~B}$ & $3.57 \mathbf{~ d}$ & $0.36 \mathbf{b c}$ & $2.48 \mathbf{b}$ & $0.67 \mathbf{~ a b}$ & $0.33 \mathbf{c}$ \\
$140 \mathrm{Ru}$ & $3.58 \mathbf{c d}$ & $0.38 \mathbf{b}$ & $2.45 \mathbf{b c}$ & $0.66 \mathbf{a b}$ & $0.36 \mathbf{a}$ \\
SO4 & $3.84 \mathbf{b c}$ & $0.50 \mathbf{a}$ & $2.81 \mathbf{a}$ & $0.62 \mathbf{b}$ & $0.33 \mathbf{c}$ \\
$110 \mathrm{R}$ & $4.04 \mathbf{~ a b}$ & $0.29 \mathbf{d}$ & $1.39 \mathbf{e}$ & $0.33 \mathbf{c}$ & $0.14 \mathbf{d}$ \\
$1103 \mathrm{P}$ & $4.22 \mathbf{a}$ & $0.29 \mathbf{d}$ & $1.16 \mathbf{f}$ & $0.26 \mathbf{d}$ & $0.11 \mathbf{e}$ \\
Salt Creek & $3.59 \mathbf{c d}$ & $0.36 \mathbf{b c}$ & $2.23 \mathbf{c}$ & $0.69 \mathbf{a}$ & $0.34 \mathbf{b}$ \\
Harmony & $3.74 \mathbf{c d}$ & $0.32 \mathbf{c d}$ & $1.72 \mathbf{d}$ & $0.64 \mathbf{~ a b}$ & $0.34 \mathbf{b}$ \\
\hline LSD \%5 & 0.26 & 0.04 & 0.23 & 0.07 & 0.01 \\
$p$ & 0.0009 & $<0.0001$ & $<0.0001$ & $<0.0001$ & $<0.0001$
\end{tabular}

${ }^{\mathrm{x}}$ Aynı sütunda farklı harflerle gösterilen ortalamalar arasında istatistiki düzeyde önemli farklılık bulunmaktadır ( $\mathrm{p} \leq 0.05)$. Ö.D.: Önemli Değil.

Çizelge 6. Farklı asma anaçlarının in vitro'da mikro besin element konsantrasyonlar1 (ppm)

\begin{tabular}{|c|c|c|c|c|}
\hline Anaçlar & $\mathrm{Cu}$ & $\mathrm{Mn}$ & $\mathrm{Fe}$ & $\mathrm{Zn}$ \\
\hline $5 \mathrm{BB}$ & $3.21 \mathbf{a b c}^{\mathrm{x}}$ & $226.0 \mathrm{e}$ & $228.2 \mathbf{d}$ & $106.3 \mathbf{a}$ \\
\hline $41 \mathrm{~B}$ & 2.06 bc & $253.0 \mathrm{~d}$ & $169.3 \mathbf{e}$ & $57.1 \mathbf{e}$ \\
\hline $140 \mathrm{Ru}$ & 2.92 bc & 346.8 b & $310.2 \mathbf{a}$ & $69.1 \mathrm{~d}$ \\
\hline $\mathrm{SO} 4$ & $3.60 \mathbf{a b}$ & 308.1 c & $250.7 \mathrm{~cd}$ & 75.6 bc \\
\hline $110 \mathrm{R}$ & 2.46 bc & $401.8 \mathbf{a}$ & 262.7 bc & $57.1 \mathrm{e}$ \\
\hline $1103 \mathrm{P}$ & $1.77 \mathrm{c}$ & 320.1 c & $293.8 \mathbf{a b}$ & 70.7 cd \\
\hline Salt Creek & $4.62 \mathbf{a}$ & 239.3 de & 156.7 e & $79.5 \mathbf{b}$ \\
\hline Harmony & $3.42 \mathbf{a b c}$ & 240.5 de & $167.1 \mathrm{e}$ & $68.5 \mathrm{~d}$ \\
\hline LSD $\% 5$ & 1.69 & 21.9 & 33.3 & 5.8 \\
\hline$p$ & 0.0651 & $<0.0001$ & $<0.0001$ & $<0.0001$ \\
\hline
\end{tabular}

${ }^{\mathrm{x} A y n ı ~ s u ̈ t u n d a ~ f a r k l ı ~ h a r f l e r l e ~ g o ̈ s t e r i l e n ~ o r t a l a m a l a r ~ a r a s ı n d a ~ i s t a t i s t i k i ~ d u ̈ z e y d e ~ o ̈ n e m l i ~}$ farklılık bulunmaktadır ( $p \leq 0.05)$. Ö.D.: Önemli Değil.

\section{Tartışma}

Araştırmada elde edilen en kuvvetli anacın 110R, en zayıf anacın Harmony ve 5BB olduğu saptanmıştır. Sonuçlar, Çizelge 1 'de verilen anaçların gelişme kuvvetleri sütunu ile çalıșmamızdaki sürgün özellikleri parametreleri kıyaslandığında, çizelgede gösterildiği gibi 110R nispeten kuvvetli, 5BB anac1 zayıf anaç grubunda yer almıştır (Çelik, 2011). 5BB'nin Çizelge 3'de değerlendirilen durumu, Çizelge 1 ile uyumlu görülürken, Harmony anacinın çalıșmamızda saptanan sürgün özellikleri performası daha düşük kalmıştır. Anaçların özelliklerinin yer aldığ $\breve{1}_{1}$ diğer bir tabloda (Cousins, 2005) çalışmamızla uyumlu şekilde 5BB, 41B ve SO4 anaçlarının büyüme kuvvetlerinin orta düzeyde olduğu, çalıșmamızın tersine 110R anacının büyüme kuvvetlerinin orta, $1103 \mathrm{P}$ ve Salt Creek anaçlarının ise büyüme kuvvetlerinin daha yüksek olduğu belirtilmiştir. 420A, 5BB ve $1103 \mathrm{P}$ anaçlarının in vivo'da tuz stresine 


\section{Asma Anaçlarının in Vitro'da Büyüme Performansları ile Besin Elementi Alım Düzeylerinin Belirlenmesi}

toleranslarının değerlendirildiği bir çalıșmada en uzun sürgünler ile daha fazla kök yaş ve kuru ağırlığ1 5BB anacinda görülmüş ancak boğum sayıları $1103 \mathrm{P}$ ve 5BB anaçlarında birbirlerine benzer olmuştur (Turhan ve ark., 2005). 1103P anacı çalışmamızda kök yaş ve kuru ağırlıkları bakımından 5BB'den üstün olmuştur. Hamrouni ve ark. (2008) da in vitro da yaptıkları denemeleri sonucunda 41B anacinın 1103P ve SO4'e göre daha uzun sürgünlere sahip olduğunu, boğum sayıları bakımından SO4, 1103P ve 41B siralamasının oluştuğunu bildirilmiştir. Araştırıcıların çalışmalarında elde ettikleri boğum sayıları bizim çalışmamızda elde edilenin yarısı kadar olmuștur. In vitro koșullarda yetiștirdikleri asma anaçlarında sürgün uzunluğu ölçümleri yapan Troncoso ve ark. (1999) çalışmamızla uyumlu şekilde bu özellik bakımından 110R, Salt Creek, 140Ru ve 41B siralamasinı elde etmişlerdir. 110R ve Salt Creek anaçlarını $1 \mathrm{mg}$ $\mathrm{L}^{-1} \mathrm{BA}$ ve $0.01 \mathrm{mg} \mathrm{L}^{-1}$ NAA içeren MS ortamında yetiştiren Edriss ve ark. (2016) Salt Creek'den daha uzun sürgünler ve daha fazla sayıda boğum elde etmişlerdir. Araştırıcılara göre, 110R sürgün yaş ve kuru ağırlıkları bakımından daha iyi sonuçlar vermiştir. In vitro'da gerçekleştirilen başka çalışmalarda (Alizadeh ve ark., 2010; Barakat ve ark., 2019) kök sayılar1 belirlenen SO4 anacindan çalışmamızla uyumlu sonuçlar ortaya çıktığı belirlenmiştir. DKW (Driver and Kuniyaki Walnut) besi ortamında asma anaçlarını yetiştiren Mohsen ve ark. (2020) beş farklı (\%0, $\% 1.5, \% 3, \quad \% 4.5$ ve \%6) PEG konsantrasyonunda dört farklı asma anacında (1103P, 140Ru, Salt Creek ve Dogridge) sürgün uzunluğu ölçümlerinde $1103 \mathrm{P} \quad(5.67 \mathrm{~cm})$; boğum sayısı (13.63 adet) ile sürgün yaş ağırlığ $(0.68 \mathrm{~g})$ parametrelerinde ise Salt Creek anacının öne çıktığını ifade etmişlerdir. Aynı çalıșmada kullanılan 140Ru anacının $5.85 \mathrm{~cm}$ sürgün uzunluğu, 6.55 boğum sayıs1 ve $0.21 \mathrm{~g}$ sürgün yaş ağırlığ gibi ölçüm sonuçlarının denememizle uyum içerisinde olduğu değerlendirilmiştir. Ersöz (2009), sera koşullarında gerçekleştirdiği saksı denemesinde asma anaçlarının klorofil miktarlarını belirlemiş 5BB ve ardından 110R'nin en iyi sonuçları verdiğini, 1103P anacının ise en düşük klorofil miktarına sahip olduğunu belirtmiştir. Asma anaçlarının klorofil miktarlarını in vitro koşullarda belirleyen bazı araștırıcılar da (Edriss ve ark., 2016) 110R anacindan en iyi sonuçları elde ederken, Salt Creek anacının bu anacı takip ettiğini beyan etmişlerdir. Mohsen ve ark., (2020) in vitro koşullarda yetiştirdiği asma anaçlarının klorofil miktarlarını belirlemiş ve $140 \mathrm{Ru}$ ile $1103 \mathrm{P}$ anaçlarından en yüksek; Salt Creek anacından ise daha düşük ölçüm değerlerini elde etmişlerdir.

Çalışmamızda gerçekleștirilen bitki besin elementi analiz sonuçları ile Jones ve ark. (1991)'nın çiçeklenme dönemi için asmada belirledikleri bitki besin maddeleri sinır değerleri karşılaştırıldı̆̆ında tüm anaçlarda $\mathrm{N}$ ve $\mathrm{Mn}$ içerikleri fazla, $\mathrm{P}$ ve $\mathrm{Fe}$ konsantrasyonları yeterli bulunmuştur. 110R ve 1103P anaçlarının $\mathrm{Mg}$ ve $\mathrm{K}$ konsantrasyonları da noksan olarak değerlendirilirken, Harmony anacı $\mathrm{K}^{\prime}$ un yeterli ve $\mathrm{Mg}$ konsantrasyonunun ise noksanlık sınır değerine yakın olduğu tespit edilmiştir. Geriye kalan anaçların $\mathrm{Mg}$ konsantrasyonları yine noksanlık sınır değerine yakın olurken $\mathrm{K}$ miktarının \%2'den fazla olduğu saptanmıștır. Anaçların Zn düzeylerine bakıldığında 5BB'nin fazla, diğer anaçların yeterli düzeyde $\mathrm{Zn}$ içerdikleri belirlenmiştir (Jones ve ark., 1991). Yetiștirme ortamının mineral element bileşimi bitkilerin büyümesi ve gelişmeleri üzerinde normal düzeyde etkili olmakta fakat elementlerin yüksek konsantrasyonlarının büyüme ve gelişme üzerinde olumsuz etkileri fizyolojik sorunlara yol açabilmektedir (Alanagh ve ark., 2014). Bitkiler üzerinde yapilan araştırmalar kalsiyumun, tomurcuk oluşumu ve bazı besin elementlerinin bitki bünyesine alımını kolaylaştırmak için önemli bir faktör olduğunu göstermiştir (Jamshidi ve ark., 2016). Troncoso ve ark. (1990) in vitro koşullarda besi ortamına ekledikleri farklı dozlardaki $(0,5,10,15,20$ ve $25 \mathrm{mM}) \mathrm{NH}_{4} \mathrm{NO}_{3}$ 'in 13.3 Evex asma anac1 bitkiciklerinin azot düzeylerini $\% 1.32(0 \mathrm{mM}$ $\left.\mathrm{NH}_{4} \mathrm{NO}_{3}\right)$ - \%5.50 (25 mM $\left.\quad \mathrm{NH}_{4} \mathrm{NO}_{3}\right)$ aralığında değiş̧irdiğini belirlemişlerdir. Çalışmamızda anaçların azot konsantrasyonlarının araştırıcıların buldukları değerler arasında yer aldığı belirlenmiştir. Troncoso ve ark. (1999)'nın yine in vitro' da 


\section{Asma Anaçlarının in Vitro'da Büyüme Performansları ile Besin Elementi Alım Düzeylerinin Belirlenmesi}

gerçekleştirdikleri bir çalışmada asma anaçlarının $\mathrm{K} \quad(\% 1.63-1.93)$ ve $\mathrm{N}$ konsantrasyonu (\%3.01-3.50) çalıșmamıza göre bir miktar daha düşük olurken; anaçların $\mathrm{P}$ (\%0.44-0.67), Ca (\%0.59-0.63) ve Mg (\%0.240.27) konsantrasyonlarının çalışmamızla uyumlu miktarda olduğu değerlendirilmiştir. In vitro koşullarda $1 \mathrm{mg} \mathrm{L}^{-1} \mathrm{BAP}, 0.5 \mathrm{mg} \mathrm{L}^{-1} \mathrm{IAA}$ ve $20 \mathrm{~g}$ sakkaroz içeren $\mathrm{MS}$ ortamında gerçekleştirilen başka bir çalışmada (Popescu ve ark., 2015) araştırıcılar Amerikan asma anaçları arasında $\mathrm{P}$ elementi için $140 \mathrm{Ru}$ $(\% 0.24), \quad 5 \mathrm{BB} \quad(\% 0.22)$ ve $\mathrm{SO} 4 \quad(\% 0.19)$ sıralamasını, $\mathrm{K}$ için 5BB (\%4.17), 140Ru (\%4.07) ve SO4 (\%0.96) siralamasinı elde etmişlerdir. Calıșmamızda ise tam tersi olarak $\mathrm{P}$ ve $\mathrm{K}$ düzeyleri en yüksek olan anaç $\mathrm{SO} 4$ (sirasiyla, \%0.50 ve \%2.81) olurken, bunu 5BB (sirasiyla, \%0.37 ve \%2.48) ve $140 \mathrm{Ru}$ (sırasıyla, \%0.38 ve \%2.45) anaçları izlemiştir. Bunun nedeninin muhtemelen eksplantın alındığ1 bitkilerin bulunduğu iklim ve toprak koşullarının farklılığından kaynaklandığ 1 düşünülmektedir. Edriss ve ark. (2016)'nın in vitro' da farklı tuz stresi koșullarında $(0,25,50$, 75, 100 ve $200 \mathrm{mM}$ ) gerçekleştirdikleri çalışmalarında Salt Creek ile 110R anaçlarının besin element içerikleri belirlenmiş ve Salt Creek'in K, Ca ve Mg; 110R'nin ise Fe, $\mathrm{Zn}$ ve Mn element konsantrasyonları bakımından öne çıktığ 1 bildirilmiştir. Gerçekleştirmiş olduğumuz araştırmada $\mathrm{N}$ elementi için 110R, $\mathrm{Zn}$ için Salt Creek anacı öne çıkmıştır. Çalışmamızda $\mathrm{Mg}$ içeriği en düşük bulunan $110 \mathrm{R}$ ve 1103P anaçlarının klorofil miktarlarının da en düşük seviyelerde olduğu gözlemlenmiştir. Klorofil bileşimine giren esas mineral element olan $\mathrm{Mg}$ eksikliğinde klorofil oluşumunda sorunların yaşandığı ve sonuç olarak da yapraklarda kloroz görüldüğü belirtilmiştir (Güneş, 2009; Çelik, 2011).

\section{Sonuç}

Araştırmada kullanılan anaçlar içerisinde sürgün özellikleri açısından 110R, kök özellikleri yönünden Harmony anacının diğer anaçlardan daha güçlü bir gelişme gösterdiği sonucuna varılmıştır. Sürgün uzunluğu bakımından en zayıf anacın Harmony olduğu belirlenmiştir. Kök uzunluğu dışındaki kök sayıs1, kök yaş ve kuru ağırlığı özellikleri bakımından en düşük değerli anacın 5BB olduğu saptanmıştır. En yüksek sürgün yaş ve kuru ağırlı̆̆ $1110 \mathrm{R}$, en düşük ağırlıkların 5BB anacinda olduğu kaydedilmiştir. En yüksek SPAD okumaları 41B ve SO4, en düşük okumalar ise $110 \mathrm{R}$ ve $1103 \mathrm{P}$ anaçlarında yapılmıştır.

Besin elementi analiz sonuçlarına göre bitki bünyesinde en yüksek element değerlerinin $\mathrm{N}$ için $5 \mathrm{BB}$ ve $1103 \mathrm{P}$; $\mathrm{K}$ ve $\mathrm{P}$ için $\mathrm{SO} 4$; $\mathrm{Ca}$ için Salt Creek; Mg için $140 \mathrm{Ru}$; Cu için Salt Creek; Mn için 110R; Fe için 140Ru; Zn için 5BB anacında olduğu belirlenmiştir. 1103P bitkilerinde, yalnızca $\mathrm{N}$ konsantrasyonu diğer anaçlara göre en fazla düzeyde tespit edilirken; $\mathrm{P}, \mathrm{K}, \mathrm{Ca}, \mathrm{Mg}$ ve $\mathrm{Cu}$ konsantrasyonları en düşük miktarda tespit edilmiştir.

Sonuç olarak bu çalışmada in vitro'da yetiştirilen sekiz anacin büyüme performansı açısından 110R anac1, bitki besleme yönünden 5BB, 140Ru, SO4 ve Salt Creek anaçları öne çıkmıştır. Bitki beslemede en düşük element konsantrasyonların $41 \mathrm{~B}$ ve $1103 \mathrm{P}$ anac1 vermiştir. Çalışmamızda sekiz anaç için tek ortam kullanılmıştır. Bundan sonraki araştırmalarda in vitro'da her bir anacin köklenmesi için en ideal hormon ve konsantrasyonlarının belirlenmesinden sonra da anaçların beslenme durumlarının tekrar değerlendirilmesinde yarar olduğu kanısına varılmıştır.

\section{Teşekkür}

$\mathrm{Bu}$ çalışma Çukurova Üniversitesi Bilimsel Araştırma Projeleri Koordinasyon Birimi tarafindan desteklenmiştir (Proje No: FBA2017-9894 ve FYL-2018-10086).

\section{Kaynaklar}

Ağaoğlu, Y. S. (1999) Bilimsel ve Uygulamalı Bağcilık, Cilt 1 Asma Biyolojisi. Kavaklıdere Eğitim Yayınları No 1, Ankara.

Ağaoğlu, Y. S. (2002) Bilimsel ve Uygulamalı Bağcilık, Cilt 2 Asma Fizyolojisi. Kavaklıdere Eğitim Yayınları No 5, Ankara.

Alanagh, E. N., Garoosi, G. A., Haddad, R., Maleki, S., Landin, M., Gallego, P. P. 


\section{Asma Anaçlarının in Vitro'da Büyüme Performansları ile Besin Elementi Alım Düzeylerinin Belirlenmesi}

(2014) Design of tissue culture media for efficient Prunus rootstock micropropagation using artificial intelligence models. Plant Cell Tissue and Organ Culture 117:349-359.

Alizadeh, M., Singh, S. K., Patel, V. B., Bhattacharya, R. C., Yadav, B. P. (2010) In vitro responses of grape rootstocks to NaCl. Biologia Plantarum 54(2):381385.

Babalık, Z. (2012) Tuz ve su stresinin asmaların bazı fiziksel ve biyokimyasal özellikleri üzerine etkileri. Doktora Tezi, Süleyman Demirel Üniversitesi.

Babaoğlu, M., Gürel, E., Özcan, S. (2001). Bitki Biyoteknolojisi I. Doku Kültürü ve Uygulamaları. Selçuk Üniversitesi Vakfi Yayınları, Konya.

Barakat, A. A., Hussein, B. A., Awad, N. A., Soliman, M. H. (2019) Evaluation of the two rootstocks $\left(\mathrm{SO}_{4}\right.$ and Freedom) for the salt stress in vitro conditions. Plant Archives 19(2):500-507.

Bavaresco, L., Fregoni, M., Gambi, E. (1993) In vitro method to screen grapevine genotypes for tolerance to lime-induced chlorosis. Vitis 32:145-148.

Bremner, J. M. (1965) Total nitrogen. Methods of Soil Analysis: Part 2. Chemical and Microbiological Properties 9:1149-1178.

Cousins, P. (2005) Evolution, genetics, and breeding: Viticultural applications of the origins of our rootstocks. In: Cousins, P., Striegler, R. K. (eds.), Grapevine rootstocks: Current use, research, and application. Proceedings of the 2005 Rootstocks Symposium, February 5, 2005, 1-7. Osage Beach, Missouri, USA

Çelik, M., Kısmalı, İ. (2004) Bazı Amerikan asma anaçlarının yuvarlak çekirdeksiz üzüm çeșidinde makro mineral besin maddelerinin alımına etkileri üzerinde araştırmalar. Ege Üniversitesi Ziraat Fakültesi Dergisi 41(1):31-38.

Çelik, S. (2011) Bağcılık (Ampeloloji) Cilt-1. Avc1 Ofset, İstanbul.

Dardeniz, A., Müftüoğlu, N. M., Altay, H. (2006) Determination of salt tolerance of some American grape rootstocks.
Bangladesh Journal of Botany 35(2):143150.

Edriss, M. H., Baghdady, G. A., Abdrabboh, G. A., Abdel Aziz, H. F. (2016) In vitro responses of some grape rootstocks to salt stres. 3. International Conference on Biotechnology Applications in Agriculture (ICBAA), Benha University, Moshtohor and Sharm El-Sheikh, 5-9 April 2016, Egypt.

Ersöz, S. (2009) Asma anaçlarında (Vitis ssp.) bor ve tuz stresine tolerans mekanizmalarının stresle ilgili fizyolojik parametreler ve antioksidan enzimlerle belirlenmesi. Yüksek Lisans Tezi, Ankara Üniversitesi.

Fisarakis, I., Chartzoulakis, K., Stavrakas, D. (2001) Response of sultana vines ( $\mathrm{V}$. vinifera L.) on six rootstocks to $\mathrm{NaCl}$ salinity exposure and recovery. Agricultural Water Management 51:1327.

Fozouni, M., Abbaspour, N., Baneh, H. D. (2012) Short term response of grapevine grown hydroponically to salinity: mineral composition and growth paremeters. Vitis 51(3):95-101.

Güneş, A. (2009) Manisa-Denizli yöresinde yetiştirilen Amerikan asma anaçlarının tuzluluk ve bor toksisitesinden etkilenme durumlarının belirlenmesi. Ankara Üniversitesi Bilimsel Araştırma Projesi Kesin Raporu, Ankara.

Hale, C. R., Brien, C. J. (1978) Influence of Salt Creek rootstock on composition and quality of Shiraz grapes and wine. Vitis 17:139-146.

Hamrouni, L., Abdallah, F. B., Abdelly, C., Ghorbel, A. (2008) In vitro culture: A simple and efficient way for salt-tolerant grapevine genotype selection. Plant Biology and Pathology, Comptes Rendus Biologies 331:152-163.

Ibacache, A. G., Sierra, C. B. (2009) Influence of rootstocks on nitrogen, phosphorus and potassium content in petioles of four table grape varieties. Chilean Journal of Agricultural Research 69(4):503-508.

Jamshidi, S., Yadollahi, A., Ahmadi, H., Arab, M. M., Eftekhari, M. (2016) Predicting in 


\section{Asma Anaçlarının in Vitro'da Büyüme Performansları ile Besin Elementi Alım Düzeylerinin Belirlenmesi}

vitro culture medium macro-nutrients composition for pear rootstocks using regression analysis and neural network models. Frontiers in Plant Science 7:112.

Jones, J. B., Wolf Jr. B., Mills, H. A. (1991) Plant Analysis Handbook. Micro-Macro publishing, Inc., USA.

Kacar, B. (1972). Bitki ve toprağın kimyasal analizleri, II. Bitki Analizleri. Ankara Üniversitesi Ziraat Fakültesi Yayınları 453, Uygulama Kilavuzu 155, Ankara Üniversitesi Basımevi, Ankara.

Keller, M., Mills, L. J., Harbertson, J. F. (2012) Rootstock effects on deficit-irrigated winegrapes in a dry climate: vigor, yield formation, and fruit ripening. American Journal of Viticulture 63(1):29-39.

Mahajan, S., Tuteja, N. (2005) Cold, salinity and drought stresses: An overview. Archives of Biochemistry and Biophysics 444(2):139-158.

Meşe, N., Tangolar, S. (2019) Bazı Amerikan asma anaçlarının kurağa dayanımının in vitro'da polietilen glikol kullanılarak belirlenmesi. Yüzüncü Yll Üniversitesi Tarım Bilimleri Dergisi 29(3):466-475.

Mohsen, A. T., Stino, R. G., Abd Allatif, A. M., Zaid, N. M. (2020) In vitro evaluation of some grapevine rootstocks grown under drought stress. Plant Archives 20(1):1029-1034.

Murashige, T., Skoog, F. (1962) A revised medium for rapid growth and bio assays with tobacco tissue cultures. Physiologia Plantarum 15:473-497.

Popescu, C. F., Bejan, C., Dumitrica, R. N., Dejeu, L. C., Nedelea, G. (2015) Rootstocks and wild grapevines responses to salinity. Vitis 54:197-201.

Prinsi, B., Simeoni, F., Galbiati, M., Meggio, F., Tonelli, C., Scienza, A., Espen, L. (2021) Grapevine rootstocks differently affect physiological and molecular responses of the scion under water deficit condition. Agronomy 11(2):1-15.

Satisha, J., Prakash, G. S., Murti, G. S. R., Upreti, K. K. (2006) Response of grape rootstocks to soil moisture stress. Journal Horticulture Science 1(1):19-23.
Suarez, D. L., Celis, N., Anderson, R. G., Sandhu, D. (2019) Grape rootstock response to salinity, water and combined salinity and water stresses. Agronomy 9(6):321.

Tangolar, S. G., Büyükalaca, S., Ergenoğlu, F. (2008). High efficiency somatic embryogenesis from immature zygotic embryos of grapevine: The effect of genotype, media, 2,4-D and incubation conditions. Turkish Journal of Agriculture and Forestry 32(4):311-317.

Tangolar, S., Ergenoğlu, F. (1989) Değişik anaçların erkenci bazı üzüm çeşitlerinde yaprakların mineral besin maddesi ve çubukların karbonhidrat içerikleri üzerine etkisi. Doğa Türk Tarım ve Ormancllık Dergisi 13:1267-1283.

Troncoso, A., Matte, C., Cantos, M., Lavee S. (1999) Evaluation of salt tolerance of in vitro-grown grapevine rootstock varieties. Vitis 38:55-60.

Troncoso, A., Villegas, A., Mazuelos, C., Cantos, M. (1990) Growth and mineral composition of grape-vine rootstock cultured in vitro with different levels of ammonium nitrate. Plant NutritionPhysiology and Applications. Proceedings of the Eleventh International Plant Nutrition Colloquium, 30 July- 4 August 1989, Wageningen, The Netherlands. 553-554p.

Turhan, E., Dardeniz, A., Müftüoğlu, N. M. (2005) Bazı Amerikan asma anaçlarının tuz stresine toleranslarının belirlenmesi. Bahçe Dergisi 34(2):11-19.

Wang, Y., Chen, W. K., Gao, X. T., He, L., Yang, X. H., He, F., Duan, C. Q., Wang, J. (2019) Rootstock-mediated effects on Cabernet Sauvignon performance: Vine growth, berry ripening, flavonoids, and aromatic profiles. International Journal of Molecular Sciences 20(2):1-16.

Yılmaz, G. Ü., Tangolar, S., Daşgan, H. Y., Tangolar S. G., Y1lmaz, N. (2008) Searching of an in vitro method for evaluation of grapevine responses to iron (Fe) deficiency stress. European Journal of Horticultural Science 73(5):222-226. 